\title{
JURY SUBORNATION THROUGH JUDICIAL CONTROL
}

\author{
ROBERT G. JOHNSTON*†
}

I

INTRODUCTION

The phrase jury subornation brings to mind images of shady characters in trench coats trying to manipulate the outcome of jury deliberations by threats or bribes. Indeed, such actions constitute usurpation of the jury's basic factfinding function, but cases involving this type of activity are few and far between and are far outnumbered by a more subtle, but just as effective, method of putting a case out of reach of a jury deliberation-that of judicial subornation.

At various points in trial proceedings, a judge may assert control over a jury, directly or indirectly.' For instance, the trial judge initially decides what evidence is admissible, may question witnesses and comment on the lawyers' presentations of the case, chooses the verdict form (a general verdict with or without interrogatories or a special verdict) along with appropriate instructions, and, if he or she wishes, may comment on the evidence. Following the trial, the judge may direct a verdict, may grant a judgment notwithstanding the verdict (judgment n.o.v.) if the evidence was insufficient to support the jury's verdict, or may grant a new trial if the weight of the evidence is against the jury's verdict. Many theories can be used to rationalize this control asserted by judges over juries. In some cases, the only explanation appears to be the proclivity of the judges (like the rest of us) to assume power. ${ }^{2}$ At other times the obvious explanation is a dispute over societal goals between the judge and the jury. ${ }^{3}$

In less controversial cases, a more gentile rationalization is that the judge is

$\uparrow$ The author gratefully acknowledges the editorial assistance of Marjorie Schultz and Mary Funk.

* Professor of Law, John Marshall Law School.

1. See Hoffa v. U.S., 385 U.S. 293 (1966), rehearing denied, 386 U.S. 951 (1967). See F. JaMEs \& G. Hazard, Civil Procedure $\$ \$ 7.12$ et seq. (2d ed. 1977) for an extensive discussion of devices for controlling the jury

2. Boeing Co. v. Shipman, 411 F.2d. 365, 391 (5th Cir. 1969) (Rives, J., dissenting); Wright, The Doubtful Omniscience of Appellate Courts, 41 Mins. L. REv. 751 (1957) wherein Judge Rives and Mr. Wright respectively address "reaching for power" by appellate judges.

3. Wolfram, The Constitutional History of the Seventh Amendment, 57 Minn. L. Rev. 639, 653-56 (1973) [hereinafter cited as Wolfram]. 
better-able to decide the matter because of his or her legal training ${ }^{4}$ or that a jury is no more entitled to be unreasonable than the judge. ${ }^{5}$ In any particular case whether the judge or the jury is more capable or more reasonable is usually a matter of personal preference.

Whatever the explanation, trial judges control juries by various procedural devices, among which are the special verdict, the directed verdict and the judgment n.o.v. Some courts and commentators criticize these devices as a judicial subornation of the jury's constitutionally-mandated function.

\section{I}

\section{Is Judicial Control Subornation?}

\section{A. Common Law Developments}

The petit jury is an integral part of the American legal system. The Seventh Amendment guarantees the right to jury trial in civil cases. Further, it cautions that, ". . . no fact tried by jury, shall be otherwise re-examined in any Court of the United States, than according to the rules of common law." Adoption of the Seventh Amendment reflected a concern that the right to jury trial should be expressly contained in the Constitution ${ }^{7}$ and many state constitutions similarly guarantee the right. ${ }^{8}$

The Supreme Court defines the common law right to jury trial as it existed in England in $1791 .{ }^{9}$ It was, as is characteristic of common law rights, ${ }^{10}$ evolving in response to changing societal conditions. (Similarly, the established federal right to jury trial is constantly changing and developing, and changes in the procedural rules affecting the right are constitutionally permissible as long as the fundamental fact-finding function of the jury is retained. ${ }^{11}$ However, the historical setting in which the Seventh Amendment was adopted and the then existing English common law are the benchmarks from which the right to jury trial and the procedural rules affecting that right are measured. ${ }^{12}$

4. Currie, Thoughts on Directed Verdicts and Summary Judgments, 45 U. CHI. L. REv. 72 (1977) [hereinafter cited as Currie].

5. Id. at 74 .

6. U.S. CoNst amend. VII.

7. See, e.g., Colgrove v. Battin, 413 U.S. 149 (1973); Wolfram, supra note 3.

8. See, e.g., Hawail Const. art. I, \$ 10 ; Ill. Const. art I, § 13.

9. See, e.g., Dimick v. Schiedt, 293 U.S. 474, 476 (1935).

10. Colligan v. Cousar, 38 Ill. App. 2d 392, 405, 187 N.E. 2d 292, 298 (1963) wherein the court opined:

... that the "common law" does not consist of absolute, fixed and inflexible rules, but broad and comprehensive principles based on justice, reason and common sense, and is of judicial origin and promulgation; and its principles are susceptible of adapting to new conditions, interests and usages as the progress of society may require.

11. Colgrove v. Battin, 413 U.S. 149 (1973).

12. See generally. Wolfram, supra note 3, at 731-47. 
Research into the specific procedural rules considered at the time of adoption of the Seventh Amendment or those attendant to the common law right to jury trial does not unearth satisfying answers. ${ }^{13}$ The Seventh Amendment was a product of consensus and compromise. ${ }^{14} \mathrm{By}$ its nature, common law tends to frustrate definitive answers. Usually research results in agreement that juries decide from the evidence which of the disputed facts presented most truly reflects what occurred and apply the substantive rules given by the judge to those facts. Research gleans only generalizations regarding development of the procedural rules. Typical of these generalizations is the statement in Pedrick that

With jurors no longer chosen because of their knowledge of the facts, subsequent evolutionary developments ranging through involuntary nonsuits, demurrers to the evidence and awarding new trials, have culminated in firmly establishing the power of the court, within constitutional bounds [citations omitted] to direct a verdict for either party in appropriate circumstances [citations ommited], while firmly preserving substantially disputed factual issues for resolution by the jury. ${ }^{15}$

The right to jury trial in this country developed in response to the Crown usurping that right because petit juries often did not comply with the Crown's colonial policies. ${ }^{16}$ Colonial practices also diverged from English common law. ${ }^{17}$ Colonial juries rendered parochial verdicts: at times deciding the facts, the applicable rules of law, or the application of rules to the facts. The Crown objected to many of the verdicts and thus limited the right to jury trial by several means:

(1) Taking over the judiciary. In 1773 the Massachusetts Charter was amended by royal fiat to provide that judges' salaries would be paid by the Crown. ${ }^{18}$ When the Chief Justice accepted the Crown's salary, the local legislature (composed of angry colonists) impeached him; the royal governor overruled the impeachment. Undaunted, the colonial veniremen refused to act as jurors when the Chief Justice presided, making performance of his duties impossible.

(2) Permit the royal governor and council to review the jury's findings of fact. ${ }^{19}$ In a 1764 New York case, an appeal was allowed that permitted the governor and council to review the facts and the law as well as the application of the rules to the facts. The appeal was

\footnotetext{
13. Id. at 723 .

14. Id. at 703-05.

15. 37 Ill. 2 d at 500,229 N.E. 2 d at 508 (1967).

16. Wolfram, supra note 3 , at 654 .

17. Id. at 665 .

18. Hyman \& Tarrant, Aspects of American Trial Jury History, in The Jury System In AMERICA:

A Critical Overview 29 (1975).

19. Id.
} 
a departure from the common law writ of error to a higher court to review questions of law only.

(3) The use of admiralty courts. ${ }^{20}$ Cases could originate in or be transferred to admiralty courts. There was no right to jury trial in the courts and the Crown's judges decided cases in keeping with royal policies.

Ten colonies (of the thirteen that declared independence from England) immediately adopted constitutional guarantees of the right to jury trial. ${ }^{21}$ The remaining three adopted the right by statutory or decisional law. The right to jury trials was thus unanimously and universally accepted by the founders of this country, despite divergent local practices regarding the manner in which the jury performed its function.

\section{B. Constitutional Developments}

At the 1787 Philadelphia Constitutional Convention, the right to jury trial in civil cases was a "missing" civil liberty that caused considerable debate. Some delegates thought the right was adequately protected by the state provisions for jury trials. Others thought that it would be impossible to draft a provision detailing the right while allowing for divergent state practices. It was suggested that Congress could provide for the right by statute. Proponents of a constitutional provision for the right to jury trial persisted. During the ratification debates, they argued that the right was necessary to protect against corrupt judges and arbitrary government officials and to protect debtors from collection cases filed in federal court by creditors trying to avoid local juries. These arguments were a culmination of the colonists experiences under the Crown.

It was also thought to be a highly regarded right even though it imposed greater administrative burdens on the legal system than a bench trial. ${ }^{22}$ Jury trials are more time consuming and costly, more likely to involve trial errors-on evidentiary rulings, in articulating the law in the instructions, and in ruling on conduct of parties before the jury. The proponents were aware of the difficulties in defining the incidents of jury trial yet they felt the benefit of jury trial in guarding against high-handed judges outweighed the administrative burdens in administering jury trials. The litigant's right was clearly at the court's expense.

Since that time, federal courts regularly pay homage (at least in verbiage) to the Amendment. Following the merger of law and equity, the Supreme Court cited the Seventh Amendment in ruling that when a single case

20. Parklane Hosiery Co., Inc. v. Shore, 439 U.S. 322, 340 (1979) (Rehnquist, J., dissenting).

21. Id. at 341 .

22. Id. at 340 . 
includes legal and equitable claims, and factual disputes common to both claims, the litigants are entitled to have a jury resolve the disputed common facts. $^{23}$ This was a departure from the traditional rule that once an equity court took jurisdiction of the claim, that court had jurisdiction over related claims-equitable and legal.

Regarding a failure to demand timely a jury, a court suggested the judge "would be ill-advised to apply Rule 38 technically and mechanically. Rather if the issues in the case are appropriate for trial by jury, the better course is to grant relief from an apparent waiver absent overriding circumstances." 24

In a typical comment regarding the right, the Supreme Court said "[m]aintenance of the jury as a fact-finding body is of such importance and occupies so firm a place in our history and jurisprudence . . . any curtailment of the right to a jury trial should be scrutinized with the utmost care." 25 Few other constitutional rights, when threatened by erosion by changes in procedural rules, draw as sharp dissents as those affecting the Seventh Amendment. ${ }^{26}$ Changes in the historic character of the jury or development of procedural rules attendant to jury trial indeed should be scrutinized with the utmost care. Absent compelling circumstances, all doubts about the rules should be resolved in favor of jury trial.

I I I

Judicial Devices Used to Control Juries

\section{A. Special Verdicts}

While a judge's comments to the jury regarding the lawyers' presentations of the case or comments on the evidence may strongly suggest to a jury the "correct" verdict, the judge's choice of a special verdict rather than a general verdict directly limits the jury's function. ${ }^{27}$ Unlike a general verdict which requires the jury to apply the law as given by the judge to the facts, a special verdict limits the jury to answering questions of fact posed by the judge. Once the jury answers the questions, the judge applies the rules of law to the answers. A special verdict thus restricts the jury to its most fundamental fact-

23. Beacon Theatres, Inc., v. Westover, 359 U.S. 500 (1959).

24. Ford v. Breier, 71 F.R.D. 195, 197 (E.D. Wis. 1976).

25. Dimick v. Schiedt, 293 U.S. 474, 486 (1935).

26. See, e.g., Colgrove v. Battin, 413 U.S. 149 (1973) and Parklane Hosiery Co., Inc. v. Shore, 439 U.S. 322 (1979).

27. Justices Black and Douglas dissented from the adoption of the 1963 amendments to the Federal Rules of Civil Procedure because, among other grounds, the amendments allowed the use of special verdicts which they believed subornated the jury's historic function, 374 U.S. 861 , 868; 31 F.R.D. 617, 618-19 (1963). See also Sunderland. Verdicts: General and Special, 29 YALE L.J. 253, 258-61 (1920): Skidmore v. B\&O RR. Co., 167 F.2d 54 (2nd Cir. 1948); Brown, Federal Special Verdicts: The Doubt Eliminator, Tenth Judicial Circuit Conference, 44 F.R.D. 245, 33853 (1967). 
finding function. It also eliminates, in most cases, doubts as to whether the jury understood, followed, or correctly applied the rules of law given to it in the instructions.

Unlike most special verdicts, general verdicts always require that the jury, once it settles on the facts, apply the rules as given by the judge to those facts. The instructions given in many cases are mind-boggling for the average juror; and the impact of these instructions on the jury whose members are untutored in the law is immeasurable. ${ }^{28}$ Oral instructions, even if delivered well by the judge, often leave jurors confused and frustrated. Written instructions encourage conscientious jurors to pour over the instructions for hidden meanings unconceived by the judge or the lawyers. The instructions given in some cases are entirely disregarded because they offend the sensibilities of the jurors. Whether the jury understood, followed, or correctly applied the law as given in the instructions in arriving at a general verdict is cloaked in the secrecy of a petit jury's deliberations. ${ }^{29}$

Despite the special verdict being a means of limiting, or even in some cases eliminating, rule application from the jury's deliberation, a special verdict is not an entirely satisfactory solution for restricting the jury to its fundamental fact-finding function. First, practitioners experience difficulty in drafting error-free special verdicts that include questions addressed to each fact necessary to support a judgment. ${ }^{30}$ Second, some areas of the law, such as reasonableness of a litigant's conduct, still require rule application by the jury. ${ }^{31}$ Since the special verdict is avoided by practitioners in many cases, is inappropriate in other cases, and requires rule application in yet other cases; it alone leaves the jury exercising its fact-finding function without direct judicial control. For this reason, other procedural devices by which the trial judge may control the jury have been developed. ${ }^{32}$

\section{B. Directed Verdicts and Judgments Notwithstanding the Verdict}

A directed verdict is granted by the judge at the close of the presentation of evidence if the evidence is insufficient to create a jury question. In essence, the judge takes the case away from the jury because he feels there is only one possible choice as to which party should prevail. Similarly, the purpose of a motion for judgment n.o.v. is to test whether the evidence is sufficient to support a jury's verdict.

28. Cooper, Directions for Directed Verdicts: A Compass for Federal Courts, 55 Minn. L. Rev. 903, 905 (1971) [hereinafter cited as Cooper].

29. Id.

30. E. Devitt \& C. Blackmar, Federal Jury Practice \& Instructions \$ 6.03 (1977); Halprin v. Mora, 231 F.2d 197 (3rd Cir. 1956) (Kalondner, J., dissenting).

31. Wiener, The Civil Jury Trial and the Law-Fact Distinction, 54 CAL. L. Rev. 1867, 1871-76 (1966) [hereinafter cited as Weiner]; Currie, supra note 4, at 72.

32. Galloway v. United States, 319 U.S. 372, 390 (1943); Currie, supra note 4, at 75; Cooper, supra note 28 , at 905 . 
Of these devices the judgment n.o.v. gives the trial judge greater power to control the jury. It authorizes the judge to overturn a jury's verdict and to enter a judgment contrary to the verdict. It starkly demonstrates the relative distribution of power between the judge and the jury in deciding cases. Because of their effects on the jury's fact-finding function, a directed verdict and a judgment n.o.v. clearly delineate the respective functions of the jury and the trial judge in the litigative process. Both devices necessitate a determination as to the sufficiency of the evidence presented by the parties. Nevertheless the standard applied and the analysis made to test the sufficiency of the evidence varies between and within jurisdictions from case to case ${ }^{33}$ Even worse, inconsistent standards are used within a single case. ${ }^{34}$ The result is that the constitutionally protected right to jury trial is mindlessly altered from case to case. Difficulty often stems from the vagaries inherent in the language used to define the standard to test the sufficiency of the evidence-words such as "substantial" or "overwhelming" are glib and imprecise measures. Comforting labels such as "question of fact" and "question of law" merely beg the question. To suggest that the evidence in a particular case raises a question of fact for the jury or a question of law for the judge only states the conclusory outcome as to which of the potential decisionmakers will be allowed to decide. Even more, the difficulty stems from disagreement among and within the courts regarding the extent to which the jury is dominate over or subordinate to the trial judge in the decision-making function.

IV

\section{Standards to Test Sufficiency of Evidence}

\section{A. Analysis of Present Standards}

A judgment n.o.v. is not an ordinary "procedural incident or detail" of civil jury trial. It defines the scope of the jury's fact-finding function. It delineates the point beyond which the trial judge may not constitutionally encroach on the jury's function. The use of shifting standards which cause uncertainty concerning the scope of the jury's function or the use of whimsical standards that erode the jury's function denigrate the jury's role in the litigative process. A single, intelligible standard is imperative to protect the constitutional right to jury trial.

Although the cases articulate multiple standards for testing the sufficiency of the evidence, for purposes of analysis the standards fall into two categories. The method of application of the standard is far more important than the

33. See generally, Currie, supra note 4; Cooper, supra note 28.

34. See discussion of Pennsylvania Railroad v. Chamberlain, 288 U.S. 333 (1933) wherein the Court used the "equal inference" test and the "overwhelming evidence" test, in text at note 32. See also, Petersen v. Honolulu, 53 Haw. 440, 496 P.2d 4 (1972). 
language of the standard. The first category favors the jury relative to the trial judge. It requires isolation and identification of the facts on which the judge tests the sufficiency of the evidence. It excludes any attempt at weighing the evidence. The standard in its simplest form is whether "any evidence" supports the verdict. A restatement of the standard is that it considers only those facts favorable to the verdict winner. According to Justice Black, it closely approximates the standard of the common law demurrer to the evidence $^{35}$ To the extent that it favors the jury, the any evidence standard reflects the concerns that prompted the adoption of the Seventh Amendment.

The second category favors the trial judge relative to the jury. It does not require a clear isolation and identification of the facts; rather, it views the evidence pervasively and allows the trial judge to weight it. This standard instructs the trial judge to decide if there is substantial evidence to support the verdict or if the verdict loser's evidence "overwhelmed" the verdict winner's evidence.

Another distinction between the two categories is the evidence from which the facts used to test sufficiency are drawn. The any evidence standard most appropriately addresses the evidence adduced in the chief aspects of the plaintiff's case. If, at the close of its case, the plaintiff has any evidence which satisfies the standard, that evidence also satisfies the standard at the close of the defendant's case. The any evidence standard then addresses whether the plaintiff established a prima facie case. If a prima facie case is made, the any evidence standard precludes a directed verdict at both the close of the plaintiff's case and the defendant's case. The overwhelming evidence standard most appropriately addresses the evidence adduced by both the plaintiff and the defendant. Even if the plaintiff at the close of its case has some evidence, that evidence may later be overwhelmed by the defendant's evidence.

\section{B. Judicial Development of Standards}

A look at some cases will serve to illustrate the courts' difficulty in defining and applying standards to test the sufficiency of the evidence. In Galloway $v$. United States, ${ }^{36}$ the Supreme Court ruled that a trial judge in the federal system was authorized to take a case away from the jury if the evidence was insufficient, but left unresolved the issue of the appropriate standard to be used to decide. The appropriate standard to be used remains undefined to date.

In Galloway the plaintiff brought an action for benefits under a policy insuring against total and permanent disability issued in accordance with a

35. 319 U.S. at 403-04. See also, 411 F.2d at 383 n.9 for a list of authorities cited therein; and Note, Evidence-Sufficiency for Directed Verdicts-Can a Judge Hold a Candle to Twelve Reasonable Men, 18 De Paul L. Rev. 322, 323 (1968).

36. 319 U.S. 372 (1942). 
federal statute. The plaintiff sought to prove that he was totally and permanently disabled because of a mental condition that developed while he was in active military service during World War I when the policy was in effect. The trial judge directed a verdict in favor of the defendant; the Court of Appeals and the Supreme Court affirmed the trial judge's ruling. The Supreme Court held that because of the absence of any probative facts concerning the plaintiff's condition during a five-year period within the twenty-year span during which the plaintiff claimed continuous disability, the evidence was insufficient to create a factual dispute that the plaintiff suffered total and permanent disability. In the Court's majority opinion by Justice Rutledge and the dissenting opinion by Justice Black, the historic power of the trial judge to direct a verdict was sharply debated. ${ }^{37}$

Justice Rutledge addressed what he described as a vague claim that the Seventh Amendment precluded a federal trial judge from directing a verdict in a jury trial. ${ }^{38} \mathrm{He}$ summarily ruled that repeated decisions of the Court upholding directed verdicts "for nearly a century" foreclosed the argument. ${ }^{39}$ However, in anticipation of Justice Black's dissenting opinion, Justice Rutledge further stated that "the argument from history is not convincing." 40

According to Justice Rutledge, at common law when the evidence was insufficient, a trial judge was empowered to take a case from the jury by at least two procedures: first, by a demurrer to the evidence and, second, by a motion for a new trial. The effect of a demurrer was a waiver of the right to have the jury decide the dispute. If the trial judge ruled for the movant, the movant prevailed as a matter of law; if he ruled against the movant, the movant, in essence, forfeited his case. The effect of the motion for a new trial was simply to retry the case before another jury if the movant were successful or to allow the jury verdict to stand if the movant were unsuccessful. Because the common law as adopted by the Seventh Amendment allowed the trial judge to take the case away from the jury by a demurrer to the evidence or to overturn a jury's verdict by a motion for a new trial, Justice Rutledge reasoned that a directed verdict was merely a variation of the demurrer and motion for new trial. As a matter of judicial policy he found the drastic results of the demurrer on the one hand, and the prospect of endless retrials on the other hand, to be unacceptable. If the evidence was insufficient to create a factual dispute, a litigant should have a reasonable procedure to terminate the litigation without burdening the litigant and the courts with a fruitless retrial. For Justice Rutledge, the directed verdict and judgment n.o.v. provide such a procedure.

37. Galloway v. U.S., 319 U.S. 372 (1943) (Black, J., dissenting, at 396), rehearing denied. 320 U.S. 214 (1943).

38. Galloway v. U.S. 372,388 (1943).

39. Supra note 35 , at 389 .

40. Id. 
Justice Rutledge also addressed the standard by which a trial judge should decide whether the evidence was sufficient to create a factual dispute. The standard for the common law demurrer was whether any evidence supported the nonmovant's case. While not rejecting the any evidence standard, Justice Rutledge did not adopt it. He ruled the standard "is essentially one to be worked out in particular situations and for particular types of cases." 41 Whatever the standard, he said, it should not permit mere speculation.

Justice Rutledge concluded that adoption of the motion for a directed verdict to test the sufficiency of the evidence with a standard different than that of the common law demurrer to the evidence was not precluded by the Seventh Amendment which
did not bind the federal courts to the exact procedural incidents or details of jury trial according to the common law in 1791, any more than it tied them to the common-law system of pleading or specific rules of evidence then prevail- ing. Nor were "the rules of the common law" then prevalent, including those relating to the procedure by which the judge regulated the jury's role on questions of fact, crystalized in a fixed and immutable system. On the con- trary, they were constantly changing and developing during the late eigh- teenth and early nineteenth centuries. In 1791 this process already had re- sulted in widely divergent common law rules on procedural matters among the states, and between them and England. And none of the contemporane- ous rules regarding judicial control of the evidence going to juries or its suffi- ciency to support a verdict had reached any precise, much less final, form. ${ }^{42}$

In order to decide whether the evidence in Galloway was sufficient to create a factual dispute, Justice Rutledge conceded that the evidence of total and permanent disability was sufficient for the period from 1930 through 1938; the evidence from before 1919 to 1925 was almost speculative; and the evidence from 1925 to 1930 was deficient. The plaintiff tried to establish total and permanent disability during those five years (1925-30) by expert testimony from a medical doctor. The doctor testified that the plaintiff suffered from a mental condition during the five years that resulted in his total and permanent disability. The doctor based his opinion on the evidence describing the plaintiff's conduct before the five years and diagnosis of the plaintiff's condition after the five years. Although the doctor qualified as an expert, Justice Rutledge found the medical opinion lacked probative value. He did not clearly articulate whether it lacked all probative value so as to be incredible or it was so weak in probative value to be outweighed by other evidence. He also pointedly questioned the failure of the plaintiff's wife to testify about her husband's condition during the five years, but he did not make clear the evidentiary effect of her failure to testify. The effect could be an evidentiary admission raising an inference or a judicial admission conclusively proving that the

41. Id. at 395 .

42. Id. at $390-92$. 
plaintiff was not totally and permanently disabled during the five years. If the doctor's opinion lacked all probative value, the negative effect of the wife's failure to testify would have little, if any, impact on the sufficiency of the evidence. But if the doctor's opinion was of questionable probative value, the negative effect of the wife's failure to testify would have a substantial impact on the sufficiency of the evidence. In the former situation the evidence would be insufficient because it lacked any substance; in the latter situation it would be insufficient because the weak medical opinion would be overwhelmed by the wife's failure to testify. In any event, Justice Rutledge decided the evidence was insufficient to allow the jury to find the plaintiff totally and permanently disabled during the five years. Since the plaintiff was required to prove continuous disability, the trial judge had correctly directed the verdict.

Justice Black rested his dissent on the historical importance of the Seventh Amendment. He pointed to comments of prominent political figures at the time the Constitution and Seventh Amendment were adopted which indicated no disagreement about the value or need to preserve the right to a jury trial. Rather, the comments showed disagreement as to the necessity of including an express statement in the Constitution. Some commentators assumed the right was implicitly incorporated into the Constitution; others wished to foreclose any debate by making the right express. Justice Black assumed that the importance of the right to jury trial required adoption of procedures designed to effect that right. The common law demurrer to the evidence clearly encouraged jury verdicts. A litigant faced an obvious, substantial risk when he demurred to the evidence. First, if the evidence was sufficient to create a factual dispute, the movant forfeited the case. Second, the standard for testing the sufficiency of the evidence was whether any evidence supported the nonmovant's case. Faced with this risk, Justice Black suggested that most litigants would test the sufficiency by a motion for a new trial.

Although Justice Black questioned the propriety of motions for a directed verdict, he placed the emphasis of his argument on the standard used to test the sufficiency of the evidence. In the distribution of power between the trial judge and the jury, Justice Black advocated the standard that most favored the jury by broadly defining what was a factual dispute. He decried the relaxation of the standard for directing verdicts from any evidence supporting the nonmovant's case to "whether the trial judge thought the evidence was overwhelming for the movant." 43 He suggested the latter standard allowed the trial judge to weigh the evidence in violation of the Seventh Amendment. That, he argued, was another incident of the "transition from jury supremacy to jury subornation through judicial decisions." 4

43. 319 U.S. $312,404-05$ (1943).

44. Supra note 35 , at 404 (Black, J., dissenting). 
Among the cases that Justice Black found particularly offensive was Pennsylvania Railroad Co. v. Chamberlain. ${ }^{45}$ In Chamberlain the plaintiff brought an action for wrongful death, claiming that the deceased, a railroad employee, was killed as a result of railroad's negligence. The plaintiff's evidence as to liability consisted of a single witness's testimony. The witness testified that while the deceased was working in a railroad yard in which cars were being sorted, a line of cars on which the deceased was riding was shunted onto a line of tracks, immediately followed by another line of cars on which other workers were riding. Plaintiff's witness testified that he observed the second line of cars moving faster than the line on which the deceased was riding. After making this observation, the plaintiff's witness looked away. He heard a loud crash, which was not an unusual occurrence, given the nature of the work performed in that yard. He later looked in the direction of both lines of cars and noted that they appeared to have merged. Because of the commotion in the area he went over and discovered the deceased had fallen to his death. The plaintiff's theory of the case was that a collision took place between the two lines of cars throwing the deceased under the wheels of the cars. The trial court granted the railroad's motion for a directed verdict at the close of all the evidence. The Court of Appeals reversed the trial court and the Supreme Court reversed the appellate court.

The Court first reversed on the grounds that the testimony of plaintiff's witness failed to establish a prima facie case. According to the Court, the testimony merely established equal inferences. It was equally probable that the crash that plaintiff's witness testified he heard was a result of a collision of other cars in the railroad yard as the cars in question. The Court next reversed on the grounds that the testimony of the plaintiff's sole witness was either incredible or immaterial. Because of his location, the Court ruled that the witness was not in a position to see the collision if it occurred, so that his testimony that a collision occurred, if accepted, was incredible. Incredible testimony is simply disregarded in a motion for a directed verdict. The Court ruled that if the witness in testifying had been trying to infer that a collision occurred, his testimony was immaterial. In either case the testimony should be disregarded. Therefore, absent any testimony of the collision, the plaintiff's case should be dismissed for lack of sufficient evidence. In considering all the evidence, the Court finally reversed on the grounds that even if it could accept the inference of plaintiff's sole witness that the two lines of cars collided, the inference was "overwhelmed" by the unimpeached, uncontradicted direct testimony that the collision never occurred by five other witnesses riding on the second line of cars.

Justice Rutledge's view prevailed: the Seventh Amendment right to trial

45. 288 U.S. 333 (1933). 
by jury does not bind the federal courts to the exact procedural incidents or details of jury trial according to the common law in 1791. The power of a federal trial judge to order a directed verdict in accordance with procedural rules is no longer questioned, but by failing to state a uniform standard by which a trial judge may direct a verdict, Justice Rutledge left unanswered the question in the federal courts as to the correct standard to be used in deciding when the evidence is insufficient to create a factual dispute to be resolved by a jury. Justice Black's concern that the federal courts had slipped from the restrictive standard requiring the trial judge to accept all perceived and inferred facts favorable to the nonmovant to that of allowing the trial judge to determine whether the evidence was overwhelmingly in favor of the movant was somewhat misplaced. He was correct in his analysis that the decisions stated different standards which in effect redefined the point at which the evidence created a factual dispute, but Justice Black was incorrect in his assumption that the federal courts would consistently choose and apply one that improperly subordinated the jury to the trial judge. Rather, the federal courts lack consistency in stating a standard that defines when a factual dispute is created, in deciding in a diversity case whether the federal standard or a state standard is applicable, and finally, in applying the standard chosen in factually similar cases. The confusion which results from this inconsistency is catalogued in Boeing Company v. Shipman. ${ }^{46}$

In Boeing, a diversity action for personal injuries resulting from unsafe working conditions, the trial judge denied the defendant's motion for a directed verdict and a judgment n.o.v. A panel of the Fifth Circuit affirmed. The defendant, in its petition for a rehearing, suggested that the panel failed to discuss fairly the defendant's evidence that overwhelmed the plaintiff's evidence. The court granted the petition and en banc the Fifth Circuit also affirmed the trial judge's ruling, but it overruled the panel's opinion which "contained errors of law" 47 involving a misstatement of the standard which defined a factual dispute. The Fifth Circuit court ruled that the federal standard, rather than the state standard, is applicable in diversity cases, that the applicable standard in Federal Employer's Liability Act (FELA) cases is inapplicable to other cases. It then chose a uniform standard applicable for all other cases.

The Fifth Circuit summarily ruled that in a diversity case the federal standard to determine the sufficiency of the evidence applies. It cited Planters Manufacturing Co. v. Protection Mutual Insurance Co.,${ }^{48}$ a previous decision that relied principally on the Supreme Court's opinions in Byrd v. Blue Ridge Rural

46. Boeing Co. v. Shipman, 411 F.2d 365, 368 (5th Cir. 1969).

47. Id. at 368 .

48. 380 F.2d 869 (5th Cir. 1967). 
Electric Cooperative ${ }^{49}$ and Simler $v$. Connor.$^{50}$ In both cases, the Court ruled that in a diversity case the federal law applies when federal and state law conflict regarding the right to a jury trial. In Byrd the issue was whether a federal court in a diversity case was bound, under the Erie doctrine, to follow a state law requiring the trial judge to decide if a claimant in a workmen's compensation case was an employee at the time the claim arose. The Supreme Court ruled that the policy of the Seventh Amendment, if not the Amendment itself, dictated that federal law be applied, stating:

- the inquiry here is whether the federal policy favoring jury decisions of
disputed fact questions should yield to the state rule in the interest of fur-
thering the objective that the litigation should not come out one way in the
federal court and another way in the state court.
We think that in the circumstances of this case the federal court should
not follow the state rule. It cannot be gainsaid that there is a strong federal
policy against allowing state rules to disrupt the judge-jury relationship in the
federal courts.5.

In Simler the issue was whether a federal court in a diversity case was Erie bound to follow the state law which defined whether a claim was legal or equitable. At stake, obviously, was the right to a jury trial. The Supreme Court this time ruled that the Seventh Amendment required that federal law apply. It stated:

... the right to a jury trial in the federal courts is to be determined as a matter of federal law in diversity as well as other actions. . . Only through a holding that the jury-trial right is to be determined according to federal law can the uniformity in its exercise which is demanded by the Seventh Amendment be achieved. ${ }^{52}$

The Fifth Circuit reasoned in both Planters and Boeing that if the Amendment required uniformity to protect the fundamental character of the federal legal system in providing a right to a jury trial, the Amendment also dictated that, in deciding the sufficiency of the evidence, the federal standard applies in diversity cases. The Court conceded in Boeing that application of the federal standard may affect state-created substantive rights in some cases. Despite that, and despite a continuing, unresolved disagreement among the federal courts, the Fifth Circuit concluded that "the integrity of our fact-finding processes must outweigh considerations of uniformity." ${ }_{53}$

The Court next discussed the applicability of the FELA standard to all cases in deciding whether the evidence was sufficient. It again cited the Planters ruling that the FELA standard was applicable. In Planters the Court relied

\footnotetext{
49. 356 U.S. 525 (1958).

50. 372 U.S. 221 (.1963).

51. 356 U.S. at 538 .

52. 372 U.S. at 222.

53. 411 F.2d at 370 .
} 
principally on Lavender $v . K u m^{54}$ to define the applicable standard. In Lavender, a FELA action for the wrongful death of a railroad switchman, the evidence tended to support two propositions: first, that the switchman died as a result of being hit by a mail hook extending from the side of a passing train, and, second, that he was killed by a hobo, many of whom frequented the area at night to get rides on freight trains. A jury verdict in favor of the plaintiff was reversed by the Mississippi Supreme Court, but the Supreme Court reversed. The Court conceded that, "It is true that there is evidence tending to show that it was physically and mathematically impossible for the hook to strike [the deceased]. And there are facts from which it might reasonably be inferred that [the deceased] was murdered." 55 The Court ruled that on appeal the evidence that the deceased was murdered was irrelevant in view of the jury's inference that the switchman's death occurred as a result of being hit by the hook. The Court continued:

It is no answer to say that the jury's verdict involved speculation and conjecture. Whenever facts are in dispute or the evidence is such that fairminded men may draw different inferences, a measure of speculation is required on the part of those whose duty it is to settle the dispute by choosing what seems to them to be the most reasonable inference. Only when there is a complete absence of probative facts to support the conclusion reached does a reversible error appear. ${ }^{56}$

In Planters, the Fifth Circuit went on to suggest that Lavender overruled the language in Pennsylvania Railroad that evidence which supported two equal inferences-one of liability and one of no liability-was insufficient to support a plaintiff's verdict. The court in Planters therefore defined the current federal standard for deciding the sufficiency of the evidence in FELA cases as only "when there is a complete absence of probative facts." 57 The court concluded that it perceived no rational basis for one standard in FELA cases and another standard in other cases. It ruled that since the Seventh Amendment defined the right to a jury trial, it also defined the standard to decide the sufficiency of the evidence. This ruling in Planters was short-lived, however, because the court expressly overruled itself in Boeing within two years.

The court in Boeing held that FELA cases are unique for two reasons: first, FELA cases require only the slightest degree of negligence on the part of the employer in order to establish liability, and second, the statute, although requiring some evidence of negligence, is a workmen's compensation statute designed to encourage recovery for injuries. The court concluded it was mandated by the Supreme Court to restore the "historic role of the jury in per-

\footnotetext{
54. 327 U.S. 645 (1946).

55. $I d$. at 652 .

56. Id. at 653 .

57. 380 F.2d at 874 .
} 
forming [its] function" 58 in FELA cases, but not necessarily in other cases. It unequivocally stated that "the Seventh Amendment ... does not require either expressly or impliedly, that the test of sufficiency of the evidence to create a jury question in a non-FELA federal case be the same as in an FELA case." 59

The court's ruling that the FELA standard is unique to that class of cases and not applicable to other cases brought a sharp dissent from Judge Rives, who found nothing in the statute or Amendment that justified different standards for FELA cases and other cases. Judge Rives further pointed out that the "complete absence of probative facts" standard was applied by the Supreme Court and other federal courts in non-FELA cases. Judge Rives addressed the concern of some that the inordinately large verdicts in FELA cases suggested greater need for judicial control over juries than in non-FELA cases. First, he suggested the verdicts were a result of the substantive elements of the statute. Second, he suggested that other procedural rules such as the power of the trial judge to comment to the jury on the evidence and to grant new trials when the verdict is against the weight of the evidence provide sufficient safeguards against inordinately large verdicts. A new trial, according to Judge Rives:

continues to be the safest remedy, less subject to reversal, and encroaching least on the constitutional fact-finding province of the jury. Moreover, it keeps the decision where it belongs, in the hands of the trial judge who has seen and heard the witnesses testify and observed their demeanor on the stand. A more general use of directed verdict would save the appellate judges many precious judicial man hours in these days of exploding dockets. Strange to say, however, we do not hear that factor mentioned by appellate court judges when they are reaching out for power to substitute their views for those of the jury. ${ }^{60}$

The Fifth Circuit finally ruled that the standard for directing verdicts and granting judgments n.o.v. requires the trial judge to

consider all of the evidence-not just that evidence which supports the nonmov[ant]'s case-but in the light and with all reasonable inferences most favorable to the party opposed to the motion. . . . If the facts and inferences point so strongly and overwhelmingly in favor of one party that the court believes that reasonable men could not arrive at a contrary verdict, granting of the motions is proper. On the other hand, if there is substantial evidence opposed to the motions, that is, evidence of such quality and weight that reasonable and fairminded men in the exercise of impartial judgment might reach different conclusions, the motions should be denied, and the case submitted to the jury. A mere scintilla of evidence is insufficient to present a question for the jury. The motions for directed verdict and judgment n.o.v. should not be decided by which side has the better of the case, nor should they be

58. $411 \mathrm{~F} .2 \mathrm{~d}$ at 371 .

59. Id. at 373 .

60. Id. at $390-91$. (Rives, J., concurring in part and dissenting in part.) 
granted only when there is a complete absence of probative facts to support a jury verdict. There must be a conflict in substantial evidence to create a jury question. However, it is the function of the jury as the traditional finder of facts, and not the Court, to weigh conflicting evidence and inferences, and determine the credibility of witnesses. ${ }^{61}$

The court thus rejected the FELA standard it had adopted in Planters a mere two years before for non-FELA cases. Even assuming the FELA standard is not applicable to non-FELA cases, Judge Rives expressed disagreement with the adopted standard. He expressed concern about the use of the word "substantial" - a word which can connote "either a qualitative or quantitative meaning" ${ }^{2}$ as used in the legal sense. In short, Judge Rives, reminiscent of Justice Black in Galloway, warned that the standards adopted came dangerously close to allowing the trial judge to weigh the evidence.

In Simblest $v$. Maynard, ${ }^{63}$ a diversity action for personal injuries resulting from a motor vehicle collision, the trial judge entered a judgment n.o.v. and the Second Circuit affirmed. It noted that, although the issue whether the federal standard or the Vermont standard for testing the sufficiency of the evidence controlled in a diversity case involving Vermont tort law was unresolved, under either standard the plaintiff's evidence was insufficient. The court described the Vermont standard as requiring the trial judge to view all the evidence in a light most favorable to the nonmovant to decide whether a reasonable person could find in favor of the nonmovant. It ruled that the federal standard, more restrictive of the trial judge's power than the Vermont standard, required the trial judge to consider only those facts favorable to the nonmovant and any uncontradicted, unimpeached facts unfavorable to the nonmovant to decide whether a reasonable person could find in favor of the nonmovant.

In Simblest the plaintiff was injured at a stoplight-controlled intersection when the westbound car he was driving was struck on the right side by a southbound fire truck en route to a fire. It was dark at the time of the accident, but the intersection was lighted. The plaintiff claimed the traffic light for westbound traffic was green as he approached and entered the intersection, but when he was about in the middle of the intersection, all lights in the area went out due to a power failure. Other witnesses said the lights were out for about fifteen minutes prior to the accident. The plaintiff said he looked ahead, left, and behind as he entered the intersection. He claimed he looked to the right when he was about three-quarters of the way through the intersection and saw the fire truck about twelve feet away from him. The plaintiff, whose hearing and eyesight were good, neither heard a siren nor saw flashing

61. Id. at 374-75

62. Id. at 393. (Rives, J., concurring in part and dissenting in part.)

63. 427 F.2d l (2nd Cir. 1970). 
lights on the fire truck. Although photographs of the intersection showed his view to the north was not entirely obstructed, the plaintiff testified that the view was entirely blocked as he entered the intersection. Both the defendant driver and his immediate supervisor who was riding the truck claimed the truck's siren was sounding and lights were flashing as it approached the intersection. The fire truck's driver testified that when he saw the car enter the intersection, the truck was traveling at about twenty to twenty-five miles an hour. He immediately braked the truck and swerved to the right. The truck left skid marks of fifteen feet; the car left no skid marks. The other witnesses testified that the truck's lights were flashing and all but one (the plaintiff's witness) testified that they heard the siren. A local ordinance provided that an emergency vehicle sounding its siren or flashing lights has the right-of-way.

As noted above, the Court concluded under either the federal standard or the Vermont standard for judgments n.o.v. the defendant was entitled to a directed verdict. In arriving at its conclusion, the Court of Appeals ruled as a matter of law that the plaintiff was not in a position to observe whether the truck's flashing lights were on. Therefore the plaintiff's testimony that he did not see the truck's flashing lights could not lead to the inference that the lights were not on. Since all other witnesses testified that the truck's flashing lights were on, no admissible evidence was presented otherwise. Applying the Second Circuit's federal standard for judgments n.o.v. to the facts, the trial judge is required to take all facts favorable to the nonmovant and all unimpeached, uncontradicted facts unfavorable to the nonmovant to see if a reasonable person could find in favor of the nonmovant. Applying the Vermont standard, the trial judge is required to take all the evidence in a light most favorable to the nonmovant to see if a reasonable person could find in favor of the nonmovant. Once the appellate court disallowed the inference that the truck's flashing lights were off, drawn solely from the plaintiff's testimony that he did not see the lights, the evidence was devoid of any facts showing that the truck's flashing lights were not on while the evidence was replete with testimony that the lights were on. In view of the local ordinance that gave emergency vehicles the right-of-way if its flashing lights were on, and because the evidence lacked any facts favorable to the plaintiff's contention that the lights were not on, and presented only unimpeached, uncontradicted facts unfavorable to the plaintiff, reasonable men could only conclude that the lights were on so that the truck had the right-of-way. Any other conclusion would be sheer speculation. Under either the federal standard or the state standard, then, the trial judge correctly granted the judgment n.o.v.

As expected, different states use different standards for directing a verdict. Furthermore, a single state's courts may follow different standards from case to case or may enunciate inconsistent standards within a single opinion 
without indicating which standard it is actually applying. The Illinois Supreme Court in Pedrick v. Peoria $\mathcal{E}^{2}$ Eastern $R$. R. Co. ${ }^{64}$ catalogued the various state standards for directing verdicts. It noted a range of standards from any evidence favorable to the nonmovant as precluding judgments n.o.v. to overwhelming evidence in favor of the movant as requiring judgments n.o.v. In announcing a uniform rule for Illinois, the Court ruled:

In our judgment verdicts ought to be directed and judgments n.o.v. entered only in those cases in which all of the evidence, when viewed in its aspect most favorable to the opponent, so overwhelmingly favors movant that no contrary verdict based on that evidence could ever stand. ${ }^{65}$

Having reviewed the various standards and settled on the one for Illinois, the Court applied the standard to the facts in Pedrick. The plaintiffs' injuries occurred when the car in which they were riding collided with a locomotive at a crossing. The critical question was whether the crossing lights were flashing. The Court described the plaintiff driver's testimony as equivocal and of little probative value. The driver testified first that the flashers were not operating, then that he did not know if they were operating, and finally that he did not see them operating. The driver testified also that immediately before the accident he did not see the car approaching the crossing from the opposite direction or the car directly behind him. He testified that he did not see the locomotive's headlight on or hear the locomotive's bell ringing. According to the Court, no other witness "disputed ... the operation of the bell and headlight." ${ }^{\text {"6 }}$ The plaintiff driver admitted he knew he was approaching the crossing and that he heard a whistle. The plaintiff passenger (the driver's wife) testified that she did not see the flashers operating. The plaintiff's witness, a passenger in his car and the driver's sister-in-law, testified that the flashers were not operating. The witness testified further that she, too, was suing the railroad for injuries that included diminished mental powers. She admitted making inconsistent statements about whether she heard the locomotive's whistle. The Court ruled:

When the dubious probative value of the testimony of the plaintiffs and [their witness] is considered in the light of the unequivocal testimony by persons with no apparent interest in the outcome of this lawsuit and the corroborative testimony of the railroad employees, we believe it may fairly be said that all the evidence, viewed most favorably to plaintiffs so overwhelmingly favors defendant that no contrary verdict based on this evidence could ever stand ${ }^{67}$

The court in Pedrick weighed the evidence. Nevertheless, it insisted that the distinction between directed verdicts or judgments n.o.v. and motions for a

64. 37 Ill. 2d 494, 229 N.E. 2d 504 (1967).

65. Id. at 510,229 N.E. $2 \mathrm{~d}$ at 513 .

66. Id. at 511,229 N.E. $2 \mathrm{~d}$ at 514 .

67. Id. at 510,229 N.E. $2 \mathrm{~d}$ at 513 . 
new trial because the verdict was against the weight of the evidence be clearly maintained. The need for the distinction rested, in part, on the different consequences of the motions. After directed verdicts and judgments n.o.v., the litigation is terminated in favor of the movant. In new trials the case is relitigated. For judgments n.o.v. the enunciated test is whether the verdict winner's evidence was overwhelmed by the verdict loser's evidence. In motions for a new trial because the verdict was against the weight of the evidence, the test is whether the verdict winner's evidence was against the manifest weight of all the evidence. The difference rests primarily on two distinctions: the first is the conclusiveness of the evidence; the second is on a motion for a new trial the trial judge may consider the credibility of the witnesses. The extent to which the difference rests on the conclusiveness of the evidence is one of degree based on the trial judge's evaluation of the evidence.

\section{The Effect of Using Different Standards}

Applying different standards to test the sufficiency of the evidence to the same fact situation obviously may result in different conclusions. Assuming consistency in the standard's application from case to case, the adoption of a uniform standard in a jurisdiction will dictate the relative number of cases that will be taken from the jury because the evidence is insufficient to raise a factual dispute for the jury to resolve. If a trial judge may not grant a judgment n.o.v. if any evidence supports the verdict winner's case, relatively few cases will be taken from the jury. If the trial judge may not grant a judgment n.o.v. if reasonable men could return a verdict for the verdict winner taking "all facts favorable to the nonmovant and any uncontradicted, unimpeached facts unfavorable to the nonmovant," again relatively few cases will be taken from the jury. However, if the trial judge may grant a judgment n.o.v. taking "all the evidence in a light most favorable to the nonmovant" or when the evidence overwhelmingly favors the movant, relatively more cases could be taken from the jury. The caution regarding the actual effect of the latter two standards stems from suggestion that the trial judge may weigh the evidence so that whether the evidence is insufficient permits a degree of subjectivity on the part of the judge that is not permitted by the other two standards.

Three simple variations of Simblest show that in some situations the different standards may lead to different results. Each variation assumes the plaintiff obtained a favorable verdict. The first variation assumes that the local ordinance requires both (rather than either) the fire truck's flashing lights and siren to be on in order to have the right-of-way. In this variation, the trial judge, in view of the facts stated in Simblest, should not enter a judgment n.o.v. The plaintiff (whose hearing was good) and one witness stated that they did not hear the siren. Applying the any evidence standard to this fact situation, two persons testified that one of the two requirements for compliance 
with the right-of-way ordinance was not met so the trial judge should not overturn the jury's verdict. Applying the Simblest federal standard that the trial judge shall consider all facts favorable to the nonmovant and any unimpeached, uncontradicted facts unfavorable to the nonmovant, two persons stated the siren was not on so the trial judge should not enter a judgment n.o.v. Applying the Vermont standard that the trial judge shall consider all the evidence in a light most favorable to the nonmovant or the standard that the judge shall decide whether the evidence is overwhelmingly in favor of the movant, the trial judge may, (but should be extremely hesitant to) enter a judgment n.o.v.

The second variation again assumes the ordinance requires both the truck's flashing lights and sirens to be on, but in this variation only the plaintiff testified that the siren was not on. Under the any evidence standard or the Simblest federal standard, the trial judge should not overturn the verdict. Under the Vermont standard or overwhelming evidence standard, the trial judge could with considerable certainty enter a judgment n.o.v. The plaintiff's testimony that the siren was not on would be overwhelmed by the witnesses's testimony to the contrary.

The third variation still assumes the local ordinance requires both the fire truck's flashing lights and siren to be on in order to have the right-of-way and again assumes only the plaintiff testified that the siren and lights were not on. This variation further assumes the plaintiff made an extrajudicial admission that the siren was on. Under the any evidence standard or the Simblest federal standard, the trial judge should not overturn the verdict unless the admission entirely negates the plaintiff's testimony that the siren was not on. Under the Vermont standard or the overwhelming evidence standard, the trial judge could with considerable certainty enter a judgment n.o.v.

Galloway, Boeing, and Simblest, in the federal system, and Pedrick, descriptive of state systems, illustrate the use and consequences of multiple standards for testing the sufficiency of the evidence. Each federal court seems free to choose its own standard in federal question cases, except perhaps for those arising under the FELA and its kin. ${ }^{68}$ Most federal courts seem unsure whether the federal or state standard applies in diversity cases. ${ }^{69}$

The use of multiple standards tends to increase the risk that different standards will be applied to similar fact situations within the same class of cases. When different standards are used for similar fact situations within the same class of cases, different results may be obtained. Further, multiple standards encourage application of inappropriate standards to different points

68. Boeing Co. v. Shipman, 411 F.2d 365 (5th Cir. 1969).

69. Id. at 368 n.2. Also Cooper, supra note 28, at 972; Bagalay, Directed Verdicts and the Right to Trial by Jury in Federal Courts, 42 TEx. L. Rev. 1053. 1057 (1964) [hereinafter cited as Bagalay]. 
in the litigative process when the court may direct a verdict, i.e., the overwhelming evidence standard at the close of the plaintiff's case.

In Galloway once the court excluded the doctor's opinion that the plaintiff was continuously disabled, the plaintiff had no evidence to support his claim. In Chamberlain once the court excluded the witness's testimony that the lines of cars collided, the plaintiff had no evidence of a collision. In Simblest once the court excluded the plaintiff's testimony that the flashing lights were not on, the plaintiff had no evidence that the fire truck's flashing lights were not on. In each situation, there was simply no evidence to support the plaintiff's claim at the close of its case. The overwhelming evidence standard, therefore, is inappropriate in those circumstances since there is simply no evidence to overwhelm. However, in Chamberlain, should the court include the witness's testimony that the lines of cars collided, the plaintiff has some evidence of a collision but that evidence is subsequently overwhelmed by the direct testimony of defendant's witnesses that no collision occurred. In Pedrick once the plaintiff testifies that the railroad crossing lights were not on, the plaintiff has some evidence that the lights were not on, but that evidence is overwhelmed by defendant's evidence that the lights were on. In the latter two situations either the any evidence standard or the overwhelming evidence standard may be applied. But the any evidence standard still only addresses the evidence adduced in the plaintiff's case while the overwhelming evidence standard addresses the evidence adduced by both the plaintiff and defendant. Obviously then, once the plaintiff satisfies the initial burden of proof of providing some evidence, the any evidence standard precludes a judgment n.o.v. Even when the plaintiff satisfies its initial burden of proof, the overwhelming evidence standard exposes the plaintiff to the risk of a judgment n.o.v. The defendant may adduce enough evidence in its case-in-chief to overwhelm the plaintiff's evidence. Implicit in the overwhelming evidence standard is the less stringent any evidence standard.

\section{Why Not Use Multiple Standards?}

Some commentators suggest that since the Seventh Amendment is silent on this point, multiple standards are not proscribed.$^{70}$ The argument confuses constitutional grace with public policy. The Seventh Amendment preserves the right to jury trial. It provides for the minimum constitutionally protected fact-finding function of the jury. It limits the power of the legislature and the courts with regard to the jury's function. However, no constitutional provision protects the right to a bench trial. ${ }^{71}$ The legislature and the courts are free, therefore, to expand, if possible, the jury's function beyond that minimally re-

70. Galloway v. United States, 319 U.S. 372, 395 (1943); Cooper, supra note 28, at 923.

71. Note. The Right to a Nonjury Trial, 74 HaRv. L. Rev. 1176 (1961). 
quired by the Seventh Amendment. But they are not free to contract that function.

If the any evidence standard is constitutionally required, that standard reduces to a minimum the extent to which the legislature or the courts may expand the jury's function short of eliminating judgments n.o.v. altogether. The any evidence standard simply allows the trial judge the least control possible over the jury's function. Anything less allows no control. If the overwhelming evidence standard is required, that standard allows the legislature or the courts to reduce the test for the sufficiency of the evidence in particular classes of cases as a matter of public policy to the any evidence standard.

Multiple standards for testing the sufficiency of the evidence seem more a product of confusion than constitutional grace. They may be justified as a matter of public policy. The initial argument against a constitutional provision preserving the right to jury trial stemmed from the diverse colonial and early state practices. Yet, when the Seventh Amendment was adopted, the Supreme Court rejected the diverse state practices for testing the sufficiency of the evidence in favor of the English common law. The Court's action in this regard suggests a single standard under the Seventh Amendment. Also, the Court in Byrd and Simmler chose federal rather than state law in diversity actions involving the right to jury trial. Both were based on the need for uniformity regarding the constitutionally-mandated right within the federal system. If uniformity is desirable in choice of law questions in federal jury trials, the federal standard for judgments n.o.v. should apply in diversity cases. ${ }^{72}$ Without a single federal standard, uniformity will not be achieved. To insist on uniformity between federal question cases and diversity cases without a uniform federal standard is at least inconsistent and illogical.

Predictability and consistency are important considerations in the modern litigative process. ${ }^{73}$ The former tends to expedite litigation; the latter tends to validate litigation. Modern practice encourages the use of discovery devices to obtain full disclosure of the relevant facts before trial. ${ }^{74}$ It also encourages the use of pretrial conferences and pretrial statements to narrow the issues for trial. ${ }^{75}$ Both the discovery devices and pretrial procedures tend to avoid or minimize surprise at trial. Knowledge of the relevant facts allows the litigants to apply the rules to the facts in order to predict with a reasonable degree of certainty the outcome of their case. Obviously, knowledge of both rules and

72. Bagalay, supra note 69 , at 1069-71, argues for application of the federal standard in diversity cases; but Cooper, supra note 28 , at 984 , argues for closer analysis on choice of law by "particularized exploration in terms of the categories of credibility, inference, and law application" which in the balance of competing federal and state interests may bring about different results.

73. Weiner, supra note 31 , at 1924 .

74. Hickman v. Taylor, 329 U.S. 495 (1947).

75. Clark v. Pennsylvania RR., 328 F.2d 591 (2nd Cir. 1964). 
facts is necessary in order to apply the rules and to predict the outcome. ${ }^{76}$ Vague, uncertain rules frustrate the policy of full disclosure. The litigant, therefore, is entitled to knowledge of the rules including the standard for testing the sufficiency of the evidence. Multiple, unintelligible standards fail to provide the litigant with the necessary knowledge.

Some commentators express concern about unreasonable or inconsistent verdicts. ${ }^{77}$ They suggest that such verdicts invalidate the jury system. Two different juries, given the same basic facts and the same law, might render inconsistent verdicts. When two plaintiffs, who are similarly situated and injured in the same incident, submit their respective cases to two different juries on the same evidence and same instructions, the juries may render inconsistent verdicts on the issue of liability. ${ }^{78}$ The inconsistency may result from differences as to the facts or the application of the rules to the facts. Inconsistent verdicts in such circumstances may be questioned as unfair. If juries render consistent verdicts, the verdicts (although perhaps unpopular) between themselves are fair. But even consistent verdicts may result in inconsistent judgments. Potentially, a trial judge on a motion for a judgment n.o.v. may apply different standards for testing the sufficiency of the evidence. The resulting ruling may be inconsistent judgments, ${ }^{79}$ which in such circumstances may be described as outrageous. Obviously the risk of inconsistent verdicts is substantial, while the risk of inconsistent judgments is slight. But multiple, unintelligible standards provide a real risk of inconsistent judgments between cases based on similar facts and the same law arising out of different incidents. Such judgments may invalidate the legal system.

In addition to its impact on predictability and consistency, the differences in the standards potentially affect the court caseloads. In Pedrick the court recognized in adopting the overwhelming evidence standard that:

prior arguments indicating that judges will be encouraged hereby to decide more negligence cases, thus unconstitutionally invading the province of the

76. In Galloway v. United States, 319 U.S. 372, $386-87$ (1943), Justice Rutledge points out that the record reveals that the plaintiff's lawyer consciously did not put the plaintiff's wife on the stand as a matter of tactics. In well-prepared cases, lawyers as a matter of course make tactical decisions on the facts the lawyer expects will be admitted into evidence and the rules he expects will be applied to those facts. In Galloway, for example, the plaintiff's wife was not offered as a witness to testify concerning the plaintiff's condition during the years in question, presumably because her testimony would be somewhat damaging to the plaintiff's case. Under the circumstances, the plaintiff's lawyer, as a matter of tactics, chose to try to establish the plaintiff's condition during the years in question by inference through the doctor's testimony rather than by directly through the wife's testimony.

77. See, e.g., Cooper, supra note 28 , at 905; Currie, supra note 4, at 72; Weiner, supra note 31 , at 1924-25.

78. Weiner, supra note 31 , at 1924-25.

79. While a trial judge and appellate court may choose to allow the inconsistent verdicts to stand in the circumstances described, an appellate court would undoubtedly reverse inconsistent judgments in one case if both were appealed. 
jury, and that more appeals will necessarily follow. That a substantial increase in the proportion of directed verdicts or judgments n.o.v. will be a necessary result seems highly questionable; that more appeals will result likewise seems debatable, and, in any event, the current delay at the trial level is of greater social concern than are our appellate caseloads. ${ }^{80}$

The argument suggests that the any evidence standard tends to encourage the alternative of new trials rather than judgments n.o.v. The argument is premised on the relative effectiveness of the two standards as a means for controlling the jury. The any evidence standard limits the incidence of judgments n.o.v.; while the overwhelming evidence increases their incidence. The only alternative device for overturning an unreasonable verdict is a new trial because the verdict is against the weight of the evidence.

The standard for testing whether the verdict is against the weight of the evidence for purposes of a new trial is variously stated. Depending on the court, a trial judge may grant a new trial if the verdict is against the "preponderance," "clearer" or "manifest" weight of the evidence. ${ }^{81}$ Unlike granting a judgment n.o.v., in granting a new trial a trial judge may consider the credibility of the witnesses. ${ }^{82}$ In order to protect the right to jury trial, a trial judge has greater discretion in denying than in granting a new trial. ${ }^{83}$ Thus, the rules governing new trials express the policy of refraining from interfering with the jury's fact-finding function.

The any evidence standard for granting judgments n.o.v. differs sharply from the standard for granting a new trial. It requires the isolation and identification of the facts, proscribes weighing the evidence by the trial judge, and excludes considering the credibility of the witnesses. The overwhelming evidence standard differs much less sharply from the standard for granting a new trial. It allows the weighing of the evidence by the trial judge without isolating or identifying the facts. It excludes considering the credibility of the witnesses. Although a sharp distinction exists between the consequences of a judgment n.o.v. and a new trial, the overwhelming evidence standard for judgments n.o.v. and "clearer weight of the evidence" standard for new trials is one of degree rather than of kind.

Obviously the any evidence standard that limits the trial judge's power to grant judgments n.o.v. encourages alternative grants of new trials. Since it is an interlocutory order, the grant of the new trial is not immediately appeal-

80. 37 III. 2d at 510-11, 229 N.E. 2d at 514 .

81. Aetna Casualty \& Surety v. Yeatts, 122 F.2d 350 (4th Cir. 1941) discusses the history of new trials and adopts the "clearer weight" standard; Lind v. Schenley Indus., 278 F.2d 79 (2nd Cir. 1960) refers to "preponderance" and "manifest weight" standards.

82. 122 F.2d at 354 .

83. 278 F.2d at 90 , wherein the court opines that the grant of a new trial interferes to a degree with the right to jury trial so that the appellate court must closely supervise the trial judge's discretion in granting a new trial. 
able. As a result the any evidence standard increases the likelihood of further litigation at the trial level than the overwhelming evidence standard. Regardless of which standard is adopted for testing the sufficiency of the evidence, the trial judge has the option of granting a new trial rather than a judgment n.o.v: ${ }^{84}$ This option is compatible with the procedural incidents of the common law right to trial by jury and expressly provided for by modern practice. And as noted, the overwhelming evidence standard allows a degree of subjectivity by the trial judge. Its application to the facts may result in substantially the same outcome as the any evidence standard depending upon the trial judge's personal views. In Boeing the original panel and the full court applied the any evidence and the overwhelming evidence standards respectively which resulted in the denial of a judgment n.o.v. for the defendant. Other factors also affect the course of further litigation regardless of the standard for testing the sufficiency of the evidence. A litigant's resources and expected benefits from a particular case may affect the litigant's decision at any stage of the litigation. At any time, litigants may choose to settle or even abandon litigation rather than pursue it further. The impact one standard or the other may have on court caseloads at the trial or appellate level is not measurable.

The problem is clear. The Supreme Court and other courts use multiple standards for testing the sufficiency of the evidence in jury trials. Whenever a court enters a judgment n.o.v., the procedure raises the question whether the court is unconstitutionally subordinating the jury's function to the judge's power. Multiple standards, as a matter of constitutional mandate or grace, are indefensible. The historical context in which the Seventh Amendment was adopted; the use of the English common law rather than the divergent colonial or state practices as a guide for defining the right to jury trial; and the choice of federal practices surrounding the right to jury trial in diversity cases to foster uniformity in the federal system suggest a uniform standard for testing the sufficiency of the evidence in jury trials.

\section{Conclusion}

Having rejected the use of multiple standards, one is faced with the dilemma of identifying the correct standard. Reference to the English common law is not entirely satisfying. First, as usual, the common law was in a state of

84. At common law the trial judge might grant a new trial when the evidence was insufficient. Galloway v. United States, 319 U.S. 372, 390 (1942); Aetna Casualty \& Surety v. Yeatts, 122 F.2d 350, 353-54 (4th Cir. 1941). In current federal practice the trial judge may grant a new trial in lieu of a judgment n.o.v. when the evidence was insufficient if the verdict loser fails to make a timely motion for judgment. Johnson v. New York, New Haven \& Hartford RR., 344 U.S. 48 (1952): Aetna Casualty \& Surety v. Yeatts, 122 F.2d 350, 353-54 (4th Cir. 1941). The trial judge may grant a new trial to a verdict in appropriate circumstances to fill the "gaps" in the evidence. Neely v. Martin K. Eby Constr.. 386 U.S. 317 (1967). 
flux in 1791. Second, the analogy between a common law demurrer to the evidence and the judgment n.o.v. is not entirely complete. Changes in the rules for taking the case away from the jury or overturning a jury's verdict evolved consciously and unconsciously. Third, reference to the overwhelming evidence standard at the close of the plaintiff's case is inappropriate. Historically the any evidence standard may have inadvertently crept into use as a test at the close of all the evidence. But if the standard for testing the sufficiency of the evidence in ruling on judgments n.o.v. is ascertainable historically and the analogy between the procedural predecessors to the judgment n.o.v. is nearly complete, the historic standard should be applied. But if the historic standard and the analogy is unascertainable (as it appears to be), the standard for testing the sufficiency of the evidence may be defined in the context of its impact on modern litigation.

Even considering its impact on modern litigation, the historical context and development of the constitutional right to jury trial, which cannot be ignored entirely, favors the any evidence standard. The colonists clearly favored the jury as the principal decision maker. The court's control over the jury by taking the case from the jury or overturning a jury's verdict is reduced to a minimum by the any evidence standard. The concern about "runaway" juries is unrealistic in view of the other devices such as new trials. In addition, the any evidence standard provides a degree of certainty by requiring isolation and identification of the facts to which the standard is applied. It permits the lawyers to predict reasonably the outcome of the litigation in order to plan strategy and tactics. It simply avoids transferring the cloak of secrecy from the jury's deliberations to the judge's decision making. The effect of the standards on the caseloads of different courts is unknown. To suggest that one standard or another increases caseloads at different levels of the judicial system is pure speculation. Thus, both history and the modern litigative process suggest the any evidence standard is the best remedy. 